\title{
OXYTOCYN MASSAGE USING INNOVATIVE MASSAGE TOOL AND CONVENTIONAL EFFLEURAGE TECHNIQUES TO INCREASE BREASTMILK PRODUCTION IN POST PARTUM MOTHERS
}

\author{
Nining Istighosah, Aprilia Nurtika Sari
}

School of Midwifery Dharma Husada Kediri

\begin{abstract}
Background: Exclusive breastfeeding for the first six months of life is recommended by the World Health Organization and United Nations Children's Fund. The World Health Organization (WHO) recommends exclusive breastfeeding for up to 6 months and continuous breastfeeding for up to 2 months. Exclusive breastfeeding is the most effective intervention to reduce infant mortality. It is estimated that it can prevent $13 \%$ of under-five mortality in lowincome countries. This study aimed to analyze the difference in breastmilk volume before and after the mother received the oxytocin massage using innovative massage tool and conventional effleurage techniques.

Subjects and Methods: This was a quasi-experiment study with a non-randomized control trial pretest-posttest design was conducted in Kediri from August to September 2020. The sample used was post-partum women on days 4 to 10 using purposive sampling technique. The dependent variable was amount of breast milk production. The independent variables were oxytocin massage treatment with effleurage technique, and the combination of oxytocin massage, effleurage technique and innovation massage tool. The data was analyzed by T-Test.

Results: In the oxytocin massage treatment group used the conventional Effleurage method (Mean $=42 ; \mathrm{SD}=29$ ) while in the massage treatment group using an innovative massage tool (Mean $=60 ; \mathrm{SD}=51$ ) this was very different in the control group (Mean $=3.4 ; \mathrm{SD}=8.8$ ) and it was statistically significant $(\mathrm{p}=0.005)$.

Conclusion: Giving oxytocin massage using an innovative massage device were higher than oxytocin massage using the conventional Effleurage method and massage using this innovative massage device had a statistical impact on increasing breast milk production
\end{abstract}

Keywords: oxytocin massage, breast milk production, innovative massage tool

Correspondence:

Nining Istighosah. School of Midwifery Dharma Husada Kediri. Jl. Penanggungan No. 41-A Kediri. E-mail: dealovanining@gmail.com. Mobile: +6281231352032. 